\title{
Simple Sources for Complex Problems. Where did Californians Come From in 1940?
}

\section{By Myron P. Gutmann}

To cite this article: Gutmann, M. P. (2021). Simple Sources for Complex Problems. Where did Californians Come From in 1940? Historical Life Course Studies, 10, 135-139. https://doi.org/10.51964/hlcs9582

\section{HISTORICAL LIFE COURSE STUDIES}

Not Like Everybody Else.

Essays in Honor of Kees Mandemakers

VOLUME 10, SPECIAL ISSUE 3

2021

GUEST EDITORS

Hilde Bras

Jan Kok

Richard L. Zijdeman 


\section{HISTORICAL LIFE COURSE STUDIES}

Historical Life Course Studies is the electronic journal of the European Historical Population Samples Network (EHPSNet). The journal is the primary publishing outlet for research involved in the conversion of existing European and nonEuropean large historical demographic databases into a common format, the Intermediate Data Structure, and for studies based on these databases. The journal publishes both methodological and substantive research articles.

\section{Methodological Articles}

This section includes methodological articles that describe all forms of data handling involving large historical databases, including extensive descriptions of new or existing databases, syntax, algorithms and extraction programs. Authors are encouraged to share their syntaxes, applications and other forms of software presented in their article, if pertinent, on the openjournals website.

\section{Research articles}

This section includes substantive articles reporting the results of comparative longitudinal studies that are demographic and historical in nature, and that are based on micro-data from large historical databases.

Historical Life Course Studies is a no-fee double-blind, peer-reviewed open-access journal supported by the European Science Foundation (ESF, http://www.esf.org), the Scientific Research Network of Historical Demography (FWO Flanders, http://www.historicaldemography.be) and the International Institute of Social History Amsterdam (IISH, http://socialhistory.org/). Manuscripts are reviewed by the editors, members of the editorial and scientific boards, and by external reviewers. All journal content is freely available on the internet at https://openjournals.nl/index.php/hlcs.

\section{Co-Editors-In-Chief:}

Paul Puschmann (Radboud University) \& Luciana Quaranta (Lund University)

hislives@kuleuven.be

The European Science Foundation (ESF) provides a platform for its Member Organisations to advance science and explore new directions for research at the European level. Established in 1974 as an independent non-governmental organisation, the ESF currently serves 78 Member Organisations across 30 countries. EHPS-Net is an ESF Research Networking Programme.

The European Historical Population Samples Network (EHPS-net) brings together scholars to create a common format for databases containing non-aggregated information on persons, families and households. The aim is to form an integrated and joint interface between many European and non-European databases to stimulate comparative research on the micro-level.

Visit: http://www.ehps-net.eu.
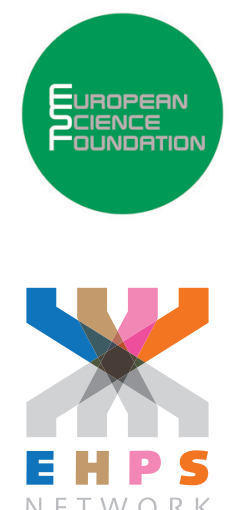


\title{
Simple Sources for Complex Problems Where did Californians Come From in 1940?
}

\author{
Myron P. Gutmann \\ The University of Colorado Boulder
}

\section{ABSTRACT}

Kees Mandemakers has been a leader in the study of linked population data, but not every society has the sources or resources to create linked data. This essay is about one approach that derives from a source that does not offer all that is possible with linked longitudinal data, but that nonetheless has significant value. Migration to California is one of the persistent refrains encountered in both popular and academic works about the history of the 1930s. The reason for this is simple. In literature and the arts, images of that migration are well known, but while those themes are accurate, they have not been sufficiently studied. My approach is to study migration using census data that ask a retrospective question about where each respondent lived five years earlier, in this case tracking migration from 1935 to 1940. Focusing on migrants to California and the paths that they took, I show that there was migration from much of the U.S. especially metropolitan areas across the country, from states near to California, and from places subject to the severe environmental shocks of the 1930s. I also show that while much of the general view of migration to California focuses on agricultural workers who left their homes in search of farm work further west, the large majority of migrants to California went to metropolitan destinations and worked as much in industry and commerce as in agriculture.

Keywords: United States, California, Migration, Census

e-ISSN: $\quad$ 2352-6343

DOI article: $\quad$ https://doi.org/10.51964/hlcs9582

The article can be downloaded from here.

\section{(C) 2021, Gutmann}

This open-access work is licensed under a Creative Commons Attribution 4.0 International License, which permits use, reproduction \& distribution in any medium for non-commercial purposes, provided the original author(s) and source are given credit. See http://creativecommons.org/licenses/. 


\section{INTRODUCTION}

All of us are indebted to the work of Kees Mandemakers for his insights into the history of population based on large scale linkage of complex data. He has demonstrated that we can learn more from such analyses than from almost any other approach to historical populations. Unfortunately, not every society has the sources or resources to create the kind of linked data systems he has modeled for us, and those of us who work in those environments make do with the resources we have. This essay is about one approach that derives from a source that does not offer all that is possible with linked longitudinal data, but that nonetheless has significant value.

Migration to California is one of the persistent refrains encountered in both popular and academic works about the history of the 1930s. The reason for this is simple. In literature and the arts, images of that migration are well known, whether they be Steinbeck's The Grapes of Wrath, or the photographs, such as Dorothea Lange in her classic photographs of impoverished migrants. Those themes are accurate but understudied. While there has not been a large volume of research about migration in the 1930s in general, general knowledge about the era's migration confirms that California was the single most important destination for the decade's migrants (Gregory, 1989; Thompson, 1955). The state received nearly four times as many net migrants as the next most popular state.

We know these details about migration in the United States between 1935 and 1940 because the U.S. Census asked respondents in the 1940 Census, exactly where they lived five years earlier, in April of 1935. Enumerators were required to ask the name of the town, county, and state where each person had lived five years earlier, plus other questions designed to pinpoint their place of origin. Full digital data files for the 1940 Census of Population from the University of Minnesota's IPUMS program make this possible.

The U.S. did not experience a lot of migration in the 1930s, at least when compared to other decades (Rosenbloom \& Sundstrom, 2004). Nevertheless, migration in the 1930s is worthy of study because of the significance of its environmental and economic drivers and the importance of westward migration in the twentieth century. We see the importance of California destinations in Panel A of Figure 1, which maps migration trajectories for individuals who moved to a metropolitan area between 1935 to 1940. In most of the country, as we might expect, metropolitan areas drew from a network of nearby counties, with most people going to the nearest metro area or one not very far away. On the other hand, for much of the western United States, where metropolitan areas were small or distant in 1940, people went to west coast cities: Seattle, Portland, San Francisco, and especially Los Angeles. Other major cities drew from large areas because of the lack of competing metro areas or their special economic strength, but nothing competes with California.

Much of the lore of migration to California is about people from the drought-stricken southern U.S. Plains going to work in cotton and vegetable fields, but there were significant streams of migrants from other regions, including cities, and more people moved to California cities than to rural counties. Understanding those migration decisions is essential to understanding the development of California and patterns of migrations in the 1930 s.

The widely known story of migration in the 1930s that we began by writing about derives much of its impact from the sense that the intense environmental shocks of the era (Cook, Seager, \& Smerdon, 2014) had a disproportionate impact on agricultural communities, and through that, on migration away from the areas that were most seriously affected. Moreover, that story also suggests that the opportunities perceived to be available in California - especially in agricultural employment - made the state a particularly attractive destination.

In this brief essay I focus on one of the most revealing aspects of the 1940 migration data: the opportunity to see migration streams and flows, because of the existence of complete-count data that do not need linkage to assess movement over time. My colleagues and I describe our procedures for working with these data in Gutmann et al. (2016). The kinds of data we utilize are well suited for this approach, even if they are far from perfect for other kinds of analysis. Their major weakness is that they reveal relatively little about people's characteristics before they move, which is where linked data are much more valuable. What we know is where they were born (and whether they had moved between birth and 1935), how old they were, whether they already had children, and their level of education, in addition to characteristics of the places that they lived in 1935. 
Figure $1 \quad$ Migrations flows from 1935 tot 1940 (as recorded in the 1940 population census)

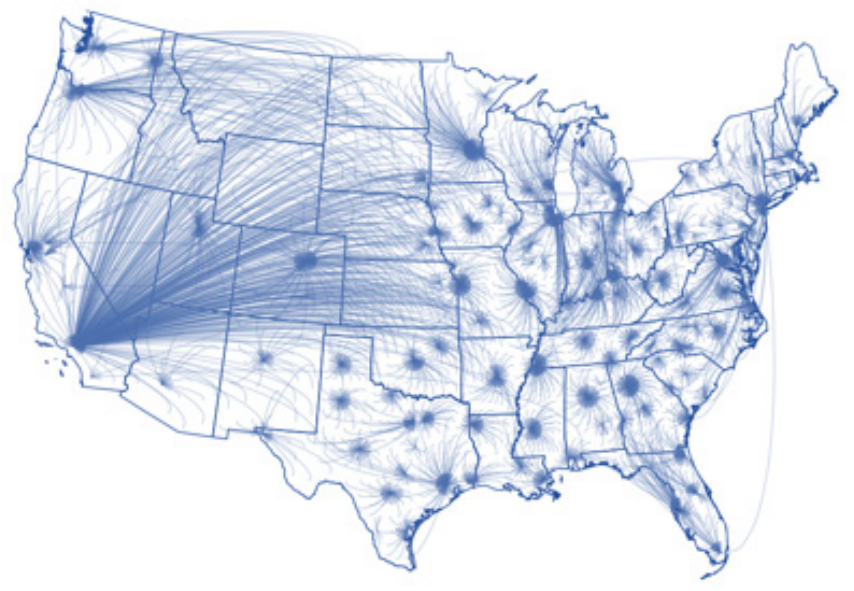

A. Top metro destination counties in 1940 for each origin county in 1935

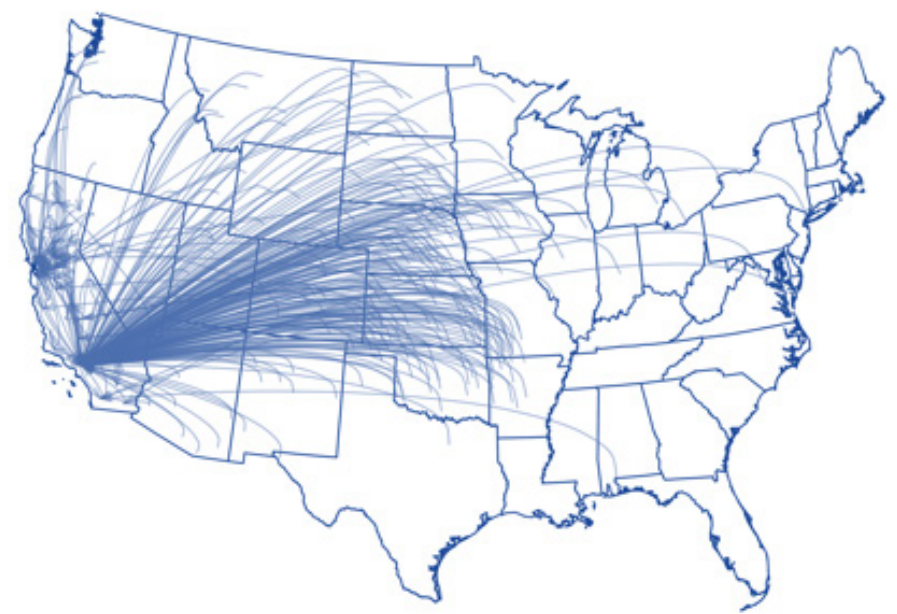

B. All flows where a California destination is one of the top 2 from a given County or Metropolitan Area

\section{MIGRATION TRAJECTORIES}

Where did immigrants to California came from in 1940? The regional categories I use do not conform with the conventional regional divisions used by the U.S. Census, which do not capture the environmental, social, or economic regions of the U.S. in a valuable way. We see the importance of the northern plains and mountains, the southwest, and the northwest (Washington and Oregon) regions for understanding migration in the 1930s - especially to California — in Table 1 and in Panel B of Figure 1. In Table 1 we show the number of California immigrants from each region of the country, as well as their percentage of the region's estimated population in 1935. While the largest number of migrants came from the South Central and Midwest regions, the largest proportions came from the Southwest, the Northwest, and the Northern Plains and Mountain states. Panel B in Figure 1 shows the migration trajectories from place to place (county or metropolitan area) where California was one of the top two destinations for people leaving that place. What we see is that California immigrants came from virtually all of the major metropolitan areas of the U.S., plus almost everywhere else west of the Mississippi. 
Table 1

California Immigrants, 1935-1940, by region of origin

\begin{tabular}{|l|r|c|}
\hline \multicolumn{1}{|c|}{ Origin region } & Migrants & \% Origin population \\
\hline Southwest & 53,029 & 3.58 \\
\hline Northwest & 42,340 & 2.50 \\
\hline Northern Plains & 49,895 & 2.11 \\
\hline South Central & 154,257 & 1.41 \\
\hline Midwest & 109,668 & 0.55 \\
\hline Northeast & 51,071 & 0.23 \\
\hline East Central & 14,242 & 0.16 \\
\hline Southeast & 8,008 & 0.13 \\
\hline
\end{tabular}

Considered by state, the largest migrant-sending states are a diverse group, including large, populous states (New York, Illinois, Texas), nearby states (Washington and Oregon), but also states strongly affected by the drought of the 1930s: Missouri, Kansas, Nebraska, Colorado, and especially Oklahoma, which sent more than $3 \%$ of its estimated 1935 population to California by 1940 . This last group of states includes a number of the places that experienced the most significant environmentally-driven migration in the 1930s, led in percentage terms by Oklahoma and Colorado, along with Oregon, a state with a challenged naturalresource economy because of the shrinkage of construction during the 1930s, and because of its proximity to California.

Thus far I have been discussing migration flows between 1935 and 1940, but the data offer another way to look at migration, taking advantage of the fact that the census record enumerates state of birth in addition to place of residence in 1935 and 1940. State of birth is much less detailed than the locations available by knowing place of residence in the census. One main conclusion is that very few adults in 1940 had been born in the western U.S., including California or our Northwest or Southwest regions. A second finding is that most people stayed in their region of birth. A third is that most international migrants started their U.S. experience in the Northeast or Midwest.

The United States was rapidly urbanizing in the first half of the twentieth century, and migration to California is part of that trend. Despite the suggestion in The Grapes of Wrath and other sources that migrants were destined for rural California, the evidence from the 1940 Census points in a different direction. More than four times as many California immigrants went to metro counties as went to non-metro counties. When we divide them by origin status we see that roughly the same number of California immigrants came from metro as non-metro origins, but almost all the metro-origin immigrants went to metro California, and more than two-thirds of California immigrants with non-metro origins also went to metro California. Even if we acknowledge that the metropolitan counties of California still had lots of agriculture, the data are striking.

We can take this analysis one step further, by examining the distribution of California immigrant origins by region and origin metro status. There were three distinct regional patterns. The large body of immigrants from the South Central and Northern Plains and Mountain regions were mostly non-metro at origin. At the other extreme were migrants from the Northeast and Midwest, who were overwhelmingly metro. In the middle were migrants from the Southwest, Northwest, Southeast, and East Central, who were more evenly divided. This confirms a view of migration to California that again should not be surprising. There were migration flows that reflected the urban industrial status of the Midwest and Northeast, and migration flows that reflected the largely agricultural character of the central part of the U.S., with its difficult weather in the 1930s, both of which drove migration to California.

The prevailing view of migration in the 1930s is in many ways still the story of the Joads in The Grapes of Wrath: people from drought-stricken areas who experienced hardship and had little human or financial capital to buffer their experience were the ones who moved, overwhelming a pre-existing migration system 
where longer distance moves privileged moves by people with more human and financial capital. In this essay I do not have space to address the human capital issues, but it is possible to say something about origins, destinations, and migration flows.

We learn more about this process by looking at information about the places that people came from. Part of the well-established story of migration to California in the 1930s suggests that the spur to migration was the environmental and agricultural shock that began to arrive in 1934, and continued on and off throughout the decade with drought, high temperatures, and dust storms. In some ways, here again migrants to California were like all migrants, but more so. All migrants between 1935 and 1940 were more likely to come from a county with high levels of crop failure in 1934, but migrants to California were even more likely to be from such a county than migrants to other states. Part of the signal that we are seeing is one of location, whether measured by distance, region, or ecological zone, or shown on a map, the most California immigrants came from places inside a zone well-defined by the regions with the worst weather.

By the 1930s the United States was an urban nation (56.1\% in 1930 and $56.5 \%$ in 1940), so it is not surprising that most migrants between 1935 and 1940 came from urban counties (even though our definition is more restrictive than the Census definition of an urban place, which includes any place with 2,500 or more inhabitants). Again, California immigrants were like other immigrants, but substantially more so, reflecting the number of available migrants from urban origin counties, even if their economic and environmental experiences were not as severe as those coming from the hardest-hit rural areas. A small majority of California immigrants came from metropolitan counties, but the world that they came to and built was overwhelmingly urban and metropolitan; three fourths of all immigrants coming into California were headed to a metropolitan county.

California was growing rapidly in the 1930s, a process driven by immigration. Taken together, the migration of the 1930s made California younger, more white, and more male, and probably somewhat less welleducated. The story is complicated by the details in the data, but it is also less surprising than one might think. California's immigration system was built on long-distance migration, drawing young, white, and relatively well-educated people. The events of the 1930s confirmed much of that overall model, but by drawing more poor and less-well-educated people from the heartland of the U.S., the system was disrupted.

\section{ACKNOWLEDGEMENTS}

I am grateful to my colleagues Angela Cunningham, Kerri Clement, Dylan Connor, and Jeremy Mikecz for their contributions to this essay. The Institute of Behavioral Science and the University of Colorado Boulder provided financial support. This research has also benefited from research, administrative, and computing support provided by the University of Colorado Population Center (CUPC; Project 2P2CHD066613), funded by the Eunice Kennedy Shriver National Institute of Child Health and Human Development (NICHD). The content is solely the responsibility of the authors and does not necessarily represent the official views of CUPC or NICHD.

\section{REFERENCES}

Cook, B. I., Seager, R., \& Smerdon, J. E. (2014). The worst North American drought year of the last millennium: 1934. Geophysical Research Letters, 41(20), 7298-7305. doi: 10.1002/2014GL061661

Gregory, J. N. (1989). American exodus: the Dust Bowl migration and Okie culture in California. New York: Oxford University Press.

Gutmann, M. P., Brown, D., Cunningham, A. R., Dykes, J., Leonard, S. H., Little, J., Mikecz, J., Rhode, P. W., Spielman, S, \& Sylvester, K. M. (2016). Migration in the 1930s: Beyond the Dust Bowl. Social Science History, 40(4), 707-740. doi: 10.1017/ssh.2016.28

Rosenbloom, J. L., \& Sundstrom, W. A. (2004). The decline and rise of interstate migration in the United States: Evidence from the IPUMS, 1850-1990. Research in Economic History, 22, 289-325. doi: 10.1016/S0363-3268(04)22006-7

Thompson, W. S. (1955). Growth and changes in California's population. Los Angeles: Haynes Foundation. 